\title{
Zasiłek chorobowy a zasiłek chorobowy z tytułu wypadku przy pracy
}

Na wstępie należy przypomnieć, że zgodnie z definicją zawartą w Kodeksie pracy ${ }^{2}$ pracownikiem może być tylko osoba fizyczna - w związku z tym, jest on narażony w miejscu pracy na różne niebezpieczeństwa związane $\mathrm{z}$ wykonywaniem pracy: czy to fizycznej, czy umysłowej, które mogą doprowadzić nawet do jego niezdolności do pracy. Niezdolność ta może być trwała lub czasowa. W niniejszym opracowaniu omówię wyłącznie skutki czasowej niezdolności do pracy.

Warto zauważyć, że ustawodawca, aby zabezpieczyć interesy pracownika, nałożył na pracodawców obowiązek obligatoryjnego ubezpieczenia społecznego. Chroni on w ten sposób nie majątek, ale zdolność pracownika do pracy ${ }^{3}$. Warto zaznaczyć w tym miejscu, że regulacje dotyczące ubezpieczeń społecznych mają podstawę konstytucyjną. Art. 67 ust. 1 najwyższego w hierarchii aktu prawnego ${ }^{4}$ wskazuje na to, że obywatel ma prawo do zabezpieczenia społecznego w razie niezdolności do pracy ze względu na chorobę lub inwalidztwo oraz po osiągnięciu wieku emerytalnego.

Zgodnie z art. 1 ustawy o systemie ubezpieczeń społecznych, ubezpieczenie społeczne obejmuje:

- ubezpieczenie emerytalne,

- ubezpieczenia rentowe,

- ubezpieczenie w razie choroby i macierzyństwa, zwane „ubezpieczeniem chorobowym",

- ubezpieczenie z tytułu wypadków przy pracy i chorób zawodowych, zwane „ubezpieczeniem wypadkowym".

Osoby, które są objęte chociażby jednym z tych ubezpieczeń, nazywa się „ubezpieczonymi” (wynika to z art. 4 pkt 1 u.s.u.s.) $)^{5}$. Podstawą objęcia tym ubezpieczeniem jest zapłata składki, która jest ustalana odrębnie dla każdego rodzaju ryzyka, ale może być płacona łącznie (tj. obejmować wszystkie rodzaje ryzyka). Warto zaznaczyć, że zakres podmiotowy każdego z tych ubezpieczeń różni się znacznie i jest szczegółowo uregulowany w przepisach prawa. Sytu-

\footnotetext{
${ }^{1}$ Student prawa, Uniwersytet Łódzki, Wydział Prawa i Administracji.

${ }^{2}$ Ustawa z dnia 26 czerwca 1974 r. Kodeks pracy, tekst jedn. Dz.U. z 2014 r., poz. 1502.

${ }_{3}^{3}$ I. Jędrasik-Jankowska, Pojęcia i konstrukcje prawne ubezpieczenia społecznego, Warszawa 2016, s. 103.

${ }^{4}$ Konstytucja Rzeczypospolitej Polskiej z dnia 2 kwietnia 1997 r., Dz.U. 1997, Nr 78, poz. 483. ${ }^{5}$ Ustawa z dnia 13 października 1998 r. o systemie ubezpieczeń społecznych, tekst jedn. Dz.U. z 2015 r., poz. 121
} 
acja pracownika została uregulowana następująco: jest on objęty wszystkimi wskazanymi powyżej rodzajami ryzyka, a składka na ubezpieczenie społeczne jest uiszczana przez pracodawcę jako jedna opłata, a nie kilka odrębnych ${ }^{6}$.

Zgodnie z art. 15 ust. 1 i 2 wspomnianej ustawy, wysokość składki na ubezpieczenie wypadkowe jest uzależniona od poziomu zagrożeń zawodowych i skutków tych zagrożeń (jest to $0,4-8,12 \%$ podstawy wymiaru), natomiast w pozostałych wypadkach stanowi ona stały odsetek wynagrodzenia dla każdego ubezpieczonego (np. dla ubezpieczenia chorobowego wynosi $2,45 \%$ podstawy wymiaru).

Pracownikowi, który utracił, czasowo lub na stałe, zdolność do wykonywania pracy, przysługuje wiele świadczeń, które są mu wypłacane przez pracodawcę albo przez państwo za pośrednictwem Zakładu Ubezpieczeń Społecznych (ZUS) z odpowiedniego funduszu ubezpieczenia.

Chciałabym bliżej zająć się tylko dwoma z nich: zasiłkiem chorobowym oraz zasiłkiem chorobowym z tytułu wypadku, ograniczając się do unormowań dotyczących tylko pracownika w rozumieniu Kodeksu pracy.

Jako pierwszy przedstawię zasiłek chorobowy, uregulowany przede wszystkim przepisami ustawy o świadczeniach pieniężnych z ubezpieczenia społecznego w razie choroby i macierzyństwa ${ }^{7}$, zwanej „ustawą zasiłkową”. w swojej pracy ograniczę się tylko do omówienia zasiłku związanego wyłącznie z chorobą, gdyż to on jest najczęściej mylony z zasiłkiem chorobowym z tytułu wypadku. Nie poruszę tym samym tematyki zasiłków związanych z macierzyństwem.

Trzeba podkreślić, że rolą zasiłku chorobowego jest przede wszystkim łagodzenie skutków finansowych niezdolności do pracy $^{8}$. Podstawą uzyskania zasiłku chorobowego jest wystąpienie choroby, którą można zdefiniować jako stan zakłócenia normalnych funkcji organizmu człowieka9 . Należy przyjąć, że prawnym początkiem choroby jest moment, w którym wpłynie ona na zdolność świadczenia pracy ${ }^{10}$. Na gruncie art. 6 ust. 2 ustawy zasiłkowej, na równi z niezdolnością do pracy z powodu choroby, traktuje się także inne wypadki, m.in. niemożność wykonywania pracy w wyniku decyzji wydanej przez właściwy organ, czy też wskutek poddania się niezbędnym badaniom lekarskim przewidzianym dla kandydatów na dawców komórek, tkanek i narządów, co poszerza katalog sytuacji, kiedy świadczenie to jest wypłacane, gdyż za chorobę uznajemy de facto te zdarzenia, które nią nie są. Należy zauważyć, że świadczenie to może być wypłacane tylko wtedy, gdy pracownik podlega ubezpieczeniu, jednakże niekiedy czasowa niezdolność do pracy może powstać już po ustaniu

\footnotetext{
${ }^{6}$ I. Jędrasik-Jankowska, op. cit., s. 44.

${ }^{7}$ Ustawa z dnia 25 czerwca 1999 r. świadczeniach pieniężnych z ubezpieczenia społecznego w razie choroby i macierzyństwa, tekst jedn. Dz.U. z 2014 r. poz. 159.

${ }^{8}$ I. Jędrasik-Jankowska, op. cit., s. 218.

${ }^{9}$ Ibidem, s. 210.

${ }^{10}$ Ibidem, s. 211.
} 
tytułu do ubezpieczenia chorobowego, w czasie trwania tzw. okresu ochronnego, który trwa co do zasady 14 dni, jednakże dla niektórych chorób został wydłużony do 3 miesięcy. Chodzi tu o takie choroby zakaźne, których okres wylęgania jest dłuższy niż 14 dni, lub innych chorób, których objawy chorobowe ujawniają się po okresie dłuższym niż 14 dni od początku choroby.

Warto zauważyć, że na gruncie Kodeksu pracy przysługuje w sytuacjach stricte określonych w art. $92 \S 1$ k.p. tzw. wynagrodzenie chorobowe, które jest wypłacane tylko wtedy, gdy pracownik ma jednocześnie prawo do zasiłku chorobowego. Zgodnie z tą regulacją pracownikowi za czas niezdolności do pracy spowodowany:

- chorobą lub odosobnieniem w związku z chorobą zakaźną (czyli ogólnym stanem zdrowia pracownika);

- wypadkiem w drodze do i z pracy albo chorobą przypadającą w trakcie ciąży;

- poddaniem się niezbędnym badaniom lekarskim przewidzianym dla kandydatów na dawców komórek, tkanek i narządów oraz poddaniem się zabiegom z tym związanych;

przysługuje za czas nieobecności trwający łącznie do 33 dni w ciągu roku kalendarzowego, a w przypadku pracownika, który ukończył 50 rok życia - trwający łącznie do 14 dni w ciągu roku kalendarzowego, wynagrodzenie od pracodawcy. Jeśli nieobecność pracownika ulegnie przedłużeniu, pracownik uzyskuje prawo do zasiłku chorobowego wypłacanego już przez ZUS. Należy zauważyć, że wysokość świadczenia płaconego przez pracodawcę, a następnie przez ZUS jest inna w zależności od przypadku, czym nieobecność pracownika jest spowodowana. W razie choroby lub odosobnienia w związku z chorobą zakaźną jest to $80 \%$ wynagrodzenia, a w pozostałych wypadkach $-100 \%$ wynagrodzenia. Wynagrodzenie to oblicza się na podstawie wymiaru zasiłku, o której będzie wspomniane później. Należy przyjąć, że zgodnie z zasadą uprzywilejowania pracownika na gruncie art. 18 k.p. (statuującego zasadę uprzywilejowania pracownika), pracodawca może zaoferować pracownikowi wyższe wynagrodzenie chorobowe. W pozostałym zakresie Kodeks pracy odsyła do „przepisów odrębnych" ustawy zasiłkowej i to jej przepisy zostaną teraz omówione.

Zasiłek chorobowy przysługuje pracownikowi tylko wtedy, jeżeli ryzyko czasowej niezdolności do pracy zaszło $\mathrm{w}$ okresie trwania ubezpieczenia chorobowego. Podkreślić trzeba, że świadczenie to nie będzie przysługiwało pracownikowi, jeżeli niezdolność do pracy na skutek choroby zaistnieje przed upływem 30 dni nieprzerwanego podlegania ubezpieczeniu. Warto zaznaczyć, że do tego okresu wlicza się także wcześniejszy okres ubezpieczenia, jeżeli przerwa w trwaniu ubezpieczenia nie była dłuższa niż 30 dni.

Wysokość zasiłku, a także wspomnianego wcześniej wynagrodzenia chorobowego, oblicza się według tzw. podstawy wymiaru, która generalnie stanowi przeciętne miesięczne wynagrodzenie wypłacone za okres 12 miesięcy 
kalendarzowych poprzedzających miesiąc, w którym nastąpiła niezdolność do pracy. Wysokość podstawy wymiaru, podanej w procentach, jest taka sama jak w przypadku wynagrodzenia chorobowego (80\% lub 100\% podstawy wymiaru), jednakże w razie pobytu pracownika w szpitalu, ulega ono obniżeniu do $70 \%$ podstawy wymiaru (art. 11 ust. 1a ustawy zasiłkowej).

Zasiłek chorobowy jest wypłacany przez okres nie dłuższy niż 182 dni, ale jeśli niezdolność do pracy jest spowodowana gruźlicą lub występuje w trakcie ciąży, okres ten ulega wydłużeniu aż do 270 dni, co wynika wprost z art. 8 ustawy zasiłkowej. Ratio legis długości tych okresów jest związane z implementacją Konwencji MOP nr 102 dotyczącej minimalnych norm zabezpieczenia społecznego ${ }^{11}$. Po tym czasie pracownikowi przysługuje świadczenie rehabilitacyjne. Niezdolność do pracy stwierdzić może tylko lekarz, wydając stosowne zaświadczenie. To na podstawie tego zaświadczenia możliwe jest wypłacanie zasiłku chorobowego.

Konieczne jest by zauważyć, że ustawodawca wprowadził pewne sytuacje, w przypadku których zaistnienia zasiłek chorobowy nie będzie pracownikowi przysługiwał. Są to:

- okres urlopu bezpłatnego,

- okres urlopu wychowawczego,

- co do zasady, okres tymczasowego aresztowania lub odbywania kary pozbawienia wolności.

Zasiłek choroby nie będzie przysługiwał pracownikowi również w przypadku, gdy pracownik na postawie innych przepisów zachowuje prawo do wynagrodzenia, np. w razie nawiązania innego stosunku pracy. Warto zauważyć, że zdarzenia te możemy więc podzielić na takie zachowania, które doprowadzają do zajścia choroby oraz na takie czyny, które nastąpiły już po wystąpieniu choroby.

Ponadto, ustawodawca przewidział szczególne sytuacje, których zaistnienie prowadzi do utraty przez pracownika zasiłku chorobowego. Są to sytuacje związane z popełnieniem przez pracownika umyślnego wykroczenia lub przestępstwa, sfałszowanie zaświadczenia lekarskiego, niepodjęcie przez pracownika, który jest nosicielem choroby zakaźnej, innej, zaproponowanej mu pracy, wykonywaniem w czasie zwolnienia innej pracy zarobkowej czy też spowodowanie niezdolności do pracy nadużyciem alkoholu. W tym ostatnim przypadku mamy do czynienia z dość ciekawym unormowaniem prawnym, bowiem ustawodawca, piętnując spożywanie alkoholu, uznał, że jeżeli niezdolność do pracy jest spowodowana nadużyciem alkoholu, zasiłek chorobowy nie może być wypłacony pracownikowi za pięć pierwszych dni (art. 15 ustawy zasiłkowej).

\footnotetext{
${ }^{11}$ Ł. Prasołek, Komentarz do art. 8 ustawy o świadczeniach pieniężnych z ubezpieczenia społecznego w razie choroby i macierzyństwa, [w:] M. Gersdorf, B. Gudowska (red.) Społeczne ubezpieczenie chorobowe i wypadkowe. Komentarz, Legalis 2012.
} 
Zasiłek chorobowy z tytułu wypadku jest zupełnie innym świadczeniem niż omówiony wcześniej zasiłek chorobowy, choć obie te instytucje są często ze sobą mylone. Regulacja tego świadczenia znajduje się w ustawie o ubezpieczeniu społecznym z tytułu wypadków przy pracy i chorób zawodowych ${ }^{12}$, zwanej ustawą wypadkową.

Zgodnie z regulacją zawarta w art. $237^{1} \S 1$ k.p. ,pracownikowi, który uległ wypadkowi przy pracy lub zachorował na chorobę zawodową przysługują świadczenia z ubezpieczenia społecznego, określone w odrębnych przepisach", czyli wspomnianych wcześniej ustawach. Jak wskazują przepisy ustawy wypadkowej, zasiłek ten przysługuje także w razie wystąpienia zdarzenia zrównanego z wypadkiem przy pracy, jeśli zdarzenie powodujące niezdolność do pracy nastąpiło w czasie podróży służbowej, w czasie szkolenia w zakresie powszechnej samoobrony czy też przy wykonywaniu zadań zleconych przez działające u pracodawcy organizacje związkowe.

Definicja wypadku przy pracy nie znajduje się w Kodeksie pracy, lecz $\mathrm{w}$ art. 3 ustawy wypadkowej. Zgodnie ze wspomnianą regulacją za wypadek przy pracy uważa się nagłe zdarzenie wywołane przyczyną zewnętrzną powodujące uraz lub śmierć, które nastąpiło w związku z pracą:

1) podczas lub w związku z wykonywaniem przez pracownika zwykłych czynności lub poleceń przełożonych;

2) podczas lub w związku $\mathrm{z}$ wykonywaniem przez pracownika czynności na rzecz pracodawcy, nawet bez polecenia;

3) w czasie pozostawania pracownika $w$ dyspozycji pracodawcy w drodze między siedzibą pracodawcy a miejscem wykonywania obowiązku wynikającego ze stosunku pracy.

Wynika stąd, że aby dane zdarzenie zostało zakwalifikowane jako wypadek przy pracy, muszą zaistnieć jednocześnie cztery elementy wskazane w przepisie: nagłe zdarzenie, zdarzenie wywołane przyczyną zewnętrzną, skutek w postaci urazu lub śmierci, związek zdarzenia z pracą.

Nagłość zdarzenia oznacza, że wypadek przy pracy ma zdarzyć się w dniu pracy, a nie „zdarzać się” przez kilka dni ${ }^{13}$. Takie rozumienie pojęcia „,nagły” pozwala na odróżnienie wyrażeń: wypadek przy pracy i choroba zawodowa ${ }^{13}$.

\footnotetext{
${ }^{12}$ Ustawa z dnia 30 października 2002 r. o ubezpieczeniu społecznym z tytułu wypadków przy pracy i chorób zawodowych, tekst jedn. Dz.U. z 2015 r., poz. 1242.

${ }^{13}$ M. Gersdorf, B. Gudowska (red.), Ustawa o ubezpieczeniu społecznym z tytulu wypadków przy pracy i chorób zawodowych, [w:] M. Gersdorf, B. Gudowska (red.) Społeczne ubezpieczenie chorobowe $i$ wypadkowe. Komentarz, Legalis 2012.
} 
Zdarzenie wywołane przyczyną zewnętrzną oznacza, że czynnik powodujący wypadek przy pracy ma pochodzić spoza organizmu pracownika - pracownik nie może w sposób świadomy wywołać wystąpienia okoliczności stanowiącej przyczynę wypadku przy pracy. Mogą to być różne czynniki: czynnik fizyczny, działanie siły fizycznej z zewnątrz, np. uderzenie ${ }^{14}$.

Skutek w postaci urazu lub śmierci to kolejna przesłanka, która musi zostać spełniona, aby dane zdarzenia móc zakwalifikować jako wypadek przy pracy. Zgodnie z art. 2 pkt. 13 ustawy wypadkowej, uraz jest określany jako „uszkodzenie tkanek ciała lub narządów człowieka wskutek działania czynnika zewnętrznego". Uraz jest określany jako przyczyna uszkodzenia ciała, czyli czynnik o charakterze zewnętrznym, oraz jako rodzaj uszkodzenia ciała. Ustalenie czy dane uszkodzenie ciała jest urazem podlega ocenie lekarskiej ${ }^{15}$. Ustawa milczy natomiast na temat tego czym jest śmierć, co oznacza, że należy przyjąć iż jest to trwałe i nieodwracalne ustanie funkcji pnia mózgu ${ }^{16}$. Uraz lub śmierć musi stwierdzić lekarz.

Związek zdarzenia z pracą oznacza, że pomiędzy zdarzeniem wywołującym szkodę, a pracą wykonywaną przez pracownika musi zachodzić związek normatywny, czyli taki, o którego istnieniu decydują przepisy prawa ${ }^{17}$.

Wypadek przy pracy stwierdza się w tzw. protokole powypadkowym, który powinien być sporządzony w ciągu 14 dni od dnia zgłoszenia przez pracownika wypadku.

Definicja choroby zawodowej znajduje się natomiast w art. 2351 k.p., a więc w zupełnie innej ustawie:

Za chorobę zawodowa uważa się chorobę, wymieniona $w$ wykazie chorób zawodowych, jeżeli $w$ wyniku oceny warunków pracy można stwierdzić bezspornie lub z wysokim prawdopodobieństwem, że została ona spowodowana działaniem czynników szkodliwych dla zdrowia wystepujacych $w$ środowisku pracy albo $w$ zwiazku ze sposobem wykonywania pracy, zwanych narażeniem zawodowym.

Choroba zawodowa jest najpierw stwierdzana przez lekarza, następnie inspektor sanitarny kwalifikuje dane schorzenie jako chorobę zawodową.

Choroby zawodowe to te, które są wymienione w wykazie chorób zawodowych, znajdującym się w załączniku do rozporządzeniu Rady Ministrów. W załączniku tym zostały wykazane choroby, które są uznawane za zawodowe oraz okres, w którym wystąpienie udokumentowanych objawów chorobowych upoważnia do rozpoznania choroby zawodowej, pomimo wcześniejszego zakoń-

\footnotetext{
${ }^{14} \mathrm{~K}$. Brzozowska, Przyczyna zewnętrzna jako cecha wypadku przy pracy, „Monitor Prawa Pracy” $10 / 2014$.

${ }^{15} \mathrm{~W}$. Witoszko, Uraz jako element definicji wypadku przy pracy, „Monitor Prawa Pracy” 6/2006.

${ }^{16}$ Ibidem.

${ }^{17}$ M. Gersdorf, B. Gudowska (red.) op. cit.
} 
czenia narażenia zawodowego. Wskazuje on aż dwadzieścia sześć grup takich chorób. Aby dana choroba mogła być uznana za zawodową musi ona spełniać dwa warunki: znajdować się w rzeczowym wykazie, a praca świadczona przez pracownika musiała być wykonywana w warunkach narażających na zachorowanie. Przykładowo, według wspomnianego wykazu, choroby zawodowe to nowotwory złośliwe, gorączka metaliczna czy pylice płuc.

Należy podkreślić, że uzyskanie świadczenia z funduszu wypadkowego jest niezależne od czasu, w jakim pracownik podlega ubezpieczeniu - zgodnie $\mathrm{z}$ art. 8 ust. 1 i 2 ustawy wypadkowej zasiłek chorobowy z tytułu wypadku przysługuje bowiem już od pierwszego dnia podlegania ubezpieczeniu - jest to regulacja o wiele korzystniejsza dla pracownika niż w przypadku zasiłku chorobowego ${ }^{18}$.

W zakresie wymiaru i podstawy zasiłku chorobowego z tytułu wypadku, ustawa wypadkowa posiłkowo odsyła do ustawy zasiłkowej. Oznacza to, że tak samo będziemy obliczać wysokość zasiłku przysługującego poszkodowanemu pracownikowi przez wypadek przy pracy, jak w przypadku zasiłku chorobowego. Okres wypłacania świadczenia także będzie taki sam - 182 lub 270 dni, z tym że pracownikowi poszkodowanemu przez wypadek przy pracy nie przysługuje wynagrodzenie chorobowe, a podstawa wymiaru zawsze wynosi $100 \%$. Po zakończeniu tego okresu, pracownikowi przysługuje świadczenie rehabilitacyjne. Pokreślić należy, że w przypadku zasiłku chorobowego z tytułu wypad$\mathrm{ku}$, pracownikowi nigdy nie będzie przysługiwało wynagrodzenie chorobowe.

Tak samo jak w przypadku zasiłku chorobowego, również tutaj ustawodawca przewidział okoliczności, które uniemożliwiają poszkodowanemu pracownikowi uzyskać zasiłek. Jest to np. spowodowanie wypadku w stanie nietrzeźwości, czy też wtedy, gdy wyłączną przyczyną wypadku było udowodnione naruszenie przez pracownika przepisów BHP. Ustawodawca wskazał także okoliczności powodujące utratę zasiłku, są to: stan nietrzeźwości lub odurzenia oraz wina umyślna lub rażące niedbalstwo poszkodowanego.

Należy zauważyć, że oba omówione przeze mnie świadczenia różnią się, ale charakteryzuje je też wiele podobieństw, m.in. wspólna regulacja co do niektórych aspektów związanych z tymi świadczeniami. Warto dodać w tym miej$\mathrm{scu}$, że zgodnie $\mathrm{z}$ art. 24 ustawy wypadkowej w razie zbiegu uprawnień do świadczeń pieniężnych $\mathrm{z}$ ubezpieczenia chorobowego $\mathrm{z}$ uprawnieniami do innych świadczeń, takich jak zasiłek chorobowy z tytuły wypadku, ubezpieczonemu przysługuje świadczenie z ubezpieczenia wypadkowego. Oznacza to, że nigdy nie dojdzie do takiej sytuacji, w których pracownik pobierałby oba te świadczenia.

${ }^{18}$ Ibidem. 
Na koniec chciałabym dodać parę uwag de lege lata i de lege ferenda dotyczących obecnego stanu prawnego. Moim zdaniem obecna regulacja nie spełnia konstytucyjnej zasady dobrej legislacji. Zarówno Kodeks pracy, jak i ustawy z zakresu ubezpieczeń społecznych należą do tych gałęzi prawa, z którym większość ludzi ma do czynienia na co dzień. Po pierwsze, interpretację przepisów utrudnia fakt, iż regulacja dotycząca obu świadczeń znajduje się nie w jednej, a w kilku ustawach, które w dodatku nawzajem do siebie odsyłają poprzez wyrażenie, że należy stosować przepisy odrębne, nie precyzując jednak o jakie regulacje dokładnie chodzi. Taka regulacja prowadzi do tego, że czasem, zanim znajdziemy odpowiednie uregulowanie, konieczne będzie posłużenie się kilkoma ustawami, co dla osoby nieobeznanej z przepisami prawnymi może być niewykonalne, a często sprawia trudności także osobom, które mają pewne doświadczenie prawnicze. Przykładem absurdu może być np. to, że definicja choroby zawodowej znajduje się w Kodeksie pracy, natomiast wypadku przy pracy już w ustawie wypadkowej, mimo że zaistnienie którejkolwiek z tych przyczyn uprawnia do otrzymywania tego samego świadczenia - zasiłku chorobowego z tytułu wypadku. Następny problem jest związany ze słowniczkami zawartymi w ustawach, które są rozbudowane, a do tego posługują się często tymi samymi pojęciami, nadając im jednak różne znaczenie. Taki sposób regulacji sprawia, że osoba, która nie zajmuje się prawem profesjonalne w ogóle nie rozumie skierowanej do niej regulacji i musi korzystać z pomocy wyspecjalizowanych podmiotów. Szczególnie rzuca się w oczy fakt, że zasiłek chorobowy $\mathrm{z}$ tytułu wypadku jest nazywany w ustawie wypadkowej po prostu zasiłkiem chorobowym, co może wprowadzać osoby niedoświadczone w błąd, że chodzi o to samo świadczenie. De lege ferenda, zgodnie z wykładnią językową i systemową przepisu, proponowałabym zmianę nazwy tego zasiłku na ,zasiłek wypadkowy", skoro jest on wypłacany z funduszu ubezpieczenia wypadkowego. Ponadto postulowałabym uchwalenie jednej ustawy, która składałaby się z trzech części: przepisów ogólnych dotyczących obu zasiłków oraz dwóch części poświęconych odrębnym rodzajom zasiłków.

\section{Bibliografia}

\section{Literatura}

Brzozowska K., Przyczyna zewnętrzna jako cecha wypadku przy pracy, „Monitor Prawa Pracy” 2014, nr 10.

Gersdorf M.,Gudowska B. (red.), Społeczne ubezpieczenie chorobowe i wypadkowe. Komentarz, Legalis 2012.

Jędrasik-Jankowska I., Pojęcia i konstrukcje prawne ubezpieczenia społecznego, Warszawa 2016. Witoszko W., Uraz jako element definicji wypadku przy pracy, „Monitor Prawa Pracy”2006, nr 6. 


\section{Akty prawne}

Konstytucja Rzeczypospolitej Polskiej z dnia 2 kwietnia 1997 r., Dz.U. z 1997 r. Nr 78, poz. 483. Ustawa z dnia 26 czerwca 1974 r. Kodeks pracy, tekst jedn. Dz.U. z 2014 r., poz. 1502.

Ustawa z dnia 13 października 1998 r. o systemie ubezpieczeń społecznych, tekst jedn. Dz.U. z 2015 r., poz. 121.

Ustawa z dnia 25 czerwca 1999 r. świadczeniach pieniężnych z ubezpieczenia społecznego w razie choroby i macierzyństwa, tekst jedn. Dz.U. z 2014 r., poz. 159.

Ustawa z dnia 30 października 2002 r. o ubezpieczeniu społecznym z tytułu wypadków przy pracy i chorób zawodowych, tekst jedn. Dz.U. z 2015 r., poz. 1242. 